\title{
Antihyperglycaemic and antihyperlipidaemic effects of aqueous ethanol extract of Tapinanthus globiferus leaves and Treculia africana root bark and their mixture on alloxan diabetic rats
}

\author{
${ }^{1}$ Ogbonnia S. O., ${ }^{2}$ Anyika E. N., ${ }^{3}$ Mbaka G. O., ${ }^{2}$ Utah P., ${ }^{2}$ Ugwu D., ${ }^{4}$ Nwakakwa N and \\ ${ }^{5}$ Ota D. A. \\ ${ }^{1}$ Department of Pharmacognosy, Faculty of Pharmacy, University of Lagos Idi- Araba, \\ Nigeria. \\ ${ }^{2}$ Department of Clinical Pharmacy and Biopharmacy, Faculty of Pharmacy, University of \\ Lagos, Idi-Araba, Lagos, Nigeria. \\ $3^{*}$ Department of Anatomy, College of Medicine, Lagos State University, Ikeja, Lagos, Nigeria. \\ ${ }^{4}$ Federal College of Complementary and Alternative Medicine, Lagos, Nigeria. \\ ${ }^{5}$ Department of Physiology, College of Medicine of the University of Lagos, Idi- Araba, \\ Lagos, Nigeria. \\ *Corresponding Author E-mail: mbaaka@yahoo.com, GSM: 234-805-8426729
}

\begin{abstract}
The plants Treculia africana and Tapinanthus globiferus are ethnobotanically used in the treatment of various diseases including diabetes and heart diseases. Diabetes mellitus is a disease characterized by hyperglycemia and hyperlipidemia which leads to an increased risk of atherosclerosis and other cardiovascular diseases. The effects of aqueous ethanol (96\%) extracts of $T$. africana leaves and Tapinanthus globiferus plants and their mixture, in an equal proportion, were evaluated on postprandial glycemic status. Four groups of normal rats were treated with the extracts at a dose $250 \mathrm{mg} / \mathrm{kg}$ each, their mixture $(1: 1)$, at a dose of $500 \mathrm{mg} / \mathrm{kg}$ body weight, $0.5 \mathrm{ml}$ of acacia $(2 \% \mathrm{w} / \mathrm{v})$ and then charged with glucose (40\%) at a dose of $1 \mathrm{ml} / 100 \mathrm{~g}$ body weight. Plasma sugar contents were analyzed from the blood collected from the tail vein at 30, 60, 90 and 120 min intervals. Also glycemic status and serum lipid profiles of normal and Alloxan-induced diabetic rats were evaluated. Five groups of alloxan-induced diabetic $(150 \mathrm{mg} / \mathrm{kg}$ ip) rats were treated with the extracts and the (1:1) mixture at a dose of $500 \mathrm{mg} / \mathrm{kg}$, respectively for 21 days. Significant reduction $(p \leq 0.05)$ in both postprandial blood glucose but not in alloxan-induced diabetes blood glucose levels, triglyceride levels, low density lipoprotein (LDL) level, and increase in high density lipoprotein (HDL) level were observed in the mixture. This scientific finding does not support the basis for the herbal use of mixture of $T$. africana and Tapinanthus globiferus in the management of diabetes and heart diseases.
\end{abstract}

Keywords: Treculia africana and Tapinanthus globiferus, acute toxicity, diabetes.

\section{INTRODUCTION}

Diabetes mellitus (DM) is a complex and multifarious group of disorders characterized by hyperglycaemia, alterations in lipid and protein metabolism due to absolute or relative lack of insulin (Walter, 1977, Noor et al., 2008). It is now recognized as one of the leading causes of death in the developing countries, where the high prevalence of the disease can be attributed to improved nutritional status coupled with a gross lack of modern facilities for the early diagnosis of the disease (Ogbonnia et al., 2010). Two main types of diabetes based on their clinical manifestations are identified as type I diabetesknown as juvenile onset or insulin sensitive diabetes and type II diabetes or non insulin dependent diabetes mellitus (NIDDM) (Gale, 2001). Type II diabetes is the more prevalent form and may have as its underlying metabolic causes the combined effects of impairment in the insulin mediated glucose disposal and defective secretion of insulin by the $\beta$ cells of the pancreas (Grundy et al., 1999). DM complications include; coronary artery disease, peripheral vascular disease, stroke, diabetic 
neuropathy, amputation, renal failure, blindness resulting in increased disability (International Diabetes federation, 2009). Diabetes has, therefore, been summarily defined as "a state of premature cardiovascular death that is associated with chronic hyperglycaemia and also associated with blindness and renal failure" (Barnett and O'Gara, 2003).

The major goals in the treatment of DM has been to keep both short-term and long-term glucose levels within acceptable limits thereby reducing the risk of long term complications (Park et al., 2009). This could be achieved by optimizing both fasting blood glucose and also postprandial glucose levels which has been found very important in achieving near normal glucose levels. Postprandial glucose levels have been reported to serve as a better maker for glycaemic control than fasting blood sugar levels (Park et al., 2009). Some drugs, therefore, have been developed to improve postprandial hyperglycaemia by inhibiting a-glucosidase activity.

Several drugs such as biguanides, sulfonylureas, thiazolidinediones, insulin, and a-glucosidase inhibitors are currently being used for the management of diabetes. However, they are associated with serious side-effects such as hypoglycaemia, flatulence, diarrhea, weight gain etc. Also they are often unable to lower glucose concentrations to within the normal range, or to reinstate a normal pattern of glucose homeostasis (Senthilvel et al., 2006). Even when effective glycaemic control is achieved, the uses of these drugs are restricted by their pharmacokinetic properties, secondary failure rates and accompanied undesirable effects (El.Nagar et al., 2005; Egwim, 2005). In addition they are not suitable for use during pregnancy (Senthilvel et al., 2006; Sushruta et al., 2006). For these reasons, there is apparent need to intensify search for an acceptable, cheap and safe blood sugar lowering oral hypoglycaemic agents that would be more effective in the treatment of diabetes and devoid of serious side effects that is associated with the currently used oral hypoglycaemic agents. There is need, therefore, for alternative therapy of plants and plant derived products being considered as the best options. (Pari and Saravanan, 2004; Ogbonnia et al., 2010).

Herbs have been used for medicinal purposes for the treatment of various diseases since prehistoric era. Plants and herb derived medicine popularly known as "Herbal medicine" is now commonly employed to manage such ailments as DM that currently could not be cured with allopathic medicines. Herbal medicine is in used by about $60 \%$ of the world population both in the developing and in the developed countries where modern medicines are predominantly used (Rickert et al., 1999; Ogbonnia et al., 2008). Tapinathus globiferus (whole plant) is used locally by the traditional herbalist for the treatment of various diseases including diabetes, and stroke. Also different parts of Treculia africana are employed for the treatment of various diseases including bacterial infections and DM locally (Odugbemi 2006; Ogbonnia et al., 2008). Herbal medicines are usually polyherbal formulations, a multi-component mixture, prepared by local herbalists and may contain various natural products as active constituents, preservatives, flavours, colouring agents etc. (Sofowora, 1993, Yinegar et al., 2008).

The aim of this research work is to investigate the claims by local herbalists the antidiabetic activity of Tapinathus globiferus and Treculia africana root bark singly and in combination in order to give scientific basis to multi-component recipes prescribed locally for the management of diabetes and also to evaluate acute toxicity of the combined therapy.

\section{MATERIALS AND METHODS}

Plant materials: The root bark of Treculia africana Decne (Moraceae) (T. africana) and leaves of Tapinanthus globiferus (A.Rich) Teigh (Loranthaceae) (T. globiferus) were collected from Ibadan in Oyo State, Nigeria on August. The root bark and leaves were identified and authenticated by a taxonomist, Mr. B Daramola at the Department of Botany, Faculty of Sciences, University of Lagos, Nigeria. The voucher specimens (no.1882 and no 1883 respectively) were deposited in the Department's Herbarium.

The plant materials were washed with tap water and spread to drain, then cut into small pieces and dried in an oven (Swallow Greenfield Oldham), at a temperature of $40^{\circ \mathrm{C}}$ for a period of seven days.

Preparation of extracts: The dried materials were subjected to size reduction to a coarse powder with electric grinder. The powdered materials of $T$. africana root bark $(795 \mathrm{~g})$ and $T$. globiferus leaves $(1030 \mathrm{~g})$ respectively, were macerated with ethanol (96\%) $4.0 \mathrm{~L}$ and allowed to stand for seven days, with regular stirring. The extract was clarified by filtration (Sofowora, 1993) using Whatman no.4 filter paper. They were then concentrated using a rotary evaporator at reduced temperature and dried with oven regulated at $40{ }^{\circ}$. The yields of the extracts 
Agric. Biol. J. N. Am., 2012, 3(6): 237-246

were $2.78 \%$ and $4.68 \%$ for $T$. africana root bark and T. globiferus leaves respectively.

Experimental animals: Male and female Swiss albino mice $(20-25 \mathrm{~g})$ and Wistar rats of both sexes weighing $140 \pm 20 \mathrm{~g}$ were obtained from the Central Animal House of the College of Medicine, University of Lagos, Idi - Araba. They were kept in plastic cages (5 per cage), fed with animal chow (Livestock feed Nigeria Ltd) and water ad libitum. The animals were housed under standard conditions of $12 \mathrm{~h}$ dark-12 h light and were allowed to acclimatize for a week.

Acute toxicity study: The toxicity study was carried out using thirty- five (35) male and female Swiss albino mice. The animals were randomly distributed into one control group and six treated groups, containing five animals per group. After being deprived food overnight, the control group received $0.3 \mathrm{ml}$ of $2 \% \mathrm{w} / \mathrm{v}$ Acacia solution orally while each treated group received orally solutions of the extract in $2 \% \mathrm{w} / \mathrm{v}$ Acacia in the doses of 1.0, 2.5, 5.0, 10.0, 15.0 and $20.0 \mathrm{mg} / \mathrm{g}$ body weight (bwt) respectively. They were closely observed in the first 4 hours and then hourly for the next 12 hours followed by 6 hourly intervals for the next 56 hours (overall $72 \mathrm{hr}$ ) after the drug administration to observe any death or changes in general behaviour and other physiological activities (Shah et al.,1997; Bürger et al., 2005).

Postprandial study: Rats were fasted over-night with free access to water (Egwim, 2005) and were divided randomly into five groups of both sexes, each containing five rats. The basal glucose levels of the animals were determined with a glucometer (Accuchek, Roche Diagnostics, Germany). The following doses were given orally to the respective group: Group 1 received mixture of the plant extracts $(1: 1)$ at the dose of $250 \mathrm{mg} / \mathrm{kg}$ bwt. Group 2 received only Treculia Africana root bark extract at the dose of 250 $\mathrm{mg} / \mathrm{kg}$ bwt. Group 3 was administered with only Tapinanthus globiferus leaves extract while Group 4 the control received $0.5 \mathrm{ml}$ of Acacia $2 \% \mathrm{w} / \mathrm{v}$ solution. After $30 \mathrm{~min}$ interval, $1 \mathrm{ml} / 100 \mathrm{~g}$ bwt of $80 \% \mathrm{w} / \mathrm{v}$ glucose solution was given orally to the animals.

Blood glucose levels were monitored with blood drawn from tail vein at 30,60 , and 120 mins and reported as the average glucose level of each group.

Fasting blood glucose study: After the animals were fasted overnight, diabetes was experimentally induced by intraperitoneal (i.p) injection of alloxan monohydrate (Sigma-Aldrich, Germany), dissolved in normal saline at a dose of $150 \mathrm{mg} / \mathrm{kg}$ bwt (Mbaka et al., 2009). After $72 \mathrm{hrs}$ of induction the blood sugar level was monitor with a glucometer (Accu-Chek, Roche Diagnostics Germany) and the rats with a blood sugar level $>200 \mathrm{mg} / \mathrm{dl}$ were classified as diabetic and used for the study. (Ogbonnia et al., 2010).

The animals were divided into seven groups with each containing five rats. Six groups were induced with diabetes while one group was not induced. All the groups were treated daily for 21 days as follows:

Group 1; diabetic rats treated with Mixture 1:1 250 $\mathrm{mg} / \mathrm{kg}$ bwt.

Group 2; diabetic rats treated with $T$. africana $250 \mathrm{mg} / \mathrm{kgbwt}$

Group 3; diabetic rats treated with $T$. globiferus $250 \mathrm{mg} / \mathrm{kg}$ bwt

Group 4; normal untreated rats (positive control)

Group 5; diabetic rats treated with Glibenclamide $600 \mathrm{ug} / \mathrm{kg}$ bwt (Ogbonnia et al., 2010)

Group 6; diabetic rats not treated

Group 7; diabetic rats treated with $0.5 \mathrm{ml}$ of Acacia $2 \% \mathrm{w} / \mathrm{v}$ (negative control)

\section{Hypolipidaemic/biochemical study}

At day 22 the animals were sacrificed under mild diethyl ether anaesthesia after 24 hrs of fast and blood was obtained via cardiac puncture into three tubes containing EDTA, fluoride oxalate and heparin respectively. The blood collected with EDTA tubes was used for haematological parameters and blood chemistry analysis while blood collected with fluoride oxalate tubes and heparinized containers was centrifuged within $5 \mathrm{~min}$ of collection at $4000 \mathrm{~g}$ for $10 \mathrm{~min}$ to obtain plasma for the determination glucose level and biochemical profiles respectively. The total cholesterol (TC), triglycerides (TG) and high density lipoprotein-cholesterol (HDL-cholesterol) levels were estimated using precipitation and modified enzymatic procedures from Sigma Diagnostics (Wasan et al., 2001). LDL-cholesterol level was calculated using Friedwald equation (Crook, 2006). Plasma was analyzed for ALT, AST and creatinine by standard enzymatic assay method and the plasma protein content was determined using enzymatic spectroscopic methods (Hussain and Eshrat, 2002).

Effects on haematological parameters: Diethyl ether was used to anaesthetize the animals before blood samples were collected through heart puncture into EDTA tubes for analysis of haematological parameters. The blood samples were analyzed for red blood cells (RBC) by haemocytometic method (Dacie and Lewis, 1984); the haemoglobin $(\mathrm{Hb})$ content was by Cyanmethaemoglobin (Drabkin) 
method (Dacie and Lewis, 1984); packed cell volume (PCV) was according to Ekaidem et al., (2006) while white blood cells (WBC) and its differentials (neutrophil, eosinophil, basophil, lymphocyte and monocyte) were as described by Dacie and Lewis (1984).

Weight variation: The animals were initially weighed and then weighed every seven days from the beginning of the treatment until the $21^{\text {st }}$ day.

Histological evaluation: The pancreatic tissues were fixed in Bouin's fluid for five days before they were embedded in paraffin wax. Each pancreatic tissue was sectioned at $5 \mu \mathrm{m}$ and mounted on a slide before staining with aldehyde fuschsin. The slide specimens were examined under light microscope at high power magnification for changes in tissue architecture and photomicrographs were taken.

\section{Preliminary phytochemical screening:} Phytochemical screening was carried out on the crude extracts of the plants to establish the presence of secondary metabolites such as alkaloids, steroidal compounds, phenolic compounds, flavonoids, saponins, tannins, anthraquinones (Farnsworth, 1966; Houghton and Raman, 1998) and for carbohydrates and proteins (Odebiyi and Sofowora, 1978).

Statistical analysis: Data were reported as Mean \pm SEM. Statistical comparison were determined by two way ANOVA and Duncan Multiple Range Test at $(p<0.05)$ and $(0.01)$ confidence limits. The difference were considered statistically significant at $p<0.05$, and $p<0.01$.

\section{RESULTS}

The acute toxicity study result (Table 1) showed that all the animals groups treated with the dose of $20 \mathrm{~g} / \mathrm{kg}$ body weight of the extracts mixture (1:1) survived beyond $24 \mathrm{hr}$ after administration.

Table 1: The results of acute toxicity test of the mixture (1:1) of the extracts

\begin{tabular}{|c|c|c|c|}
\hline $\begin{array}{c}\text { Dose } \mathrm{mg} / \mathrm{g} \\
\text { bwt }\end{array}$ & $\begin{array}{c}\text { No of } \\
\text { Rats } \\
\text { used }\end{array}$ & $\begin{array}{c}\text { Number of } \\
\text { animals } \\
\text { dead }\end{array}$ & $\begin{array}{c}\text { \% cumulative } \\
\text { Death of mice }\end{array}$ \\
\hline Control & 5 & 0 & 0 \\
\hline 2.5 & 5 & 0 & 0 \\
\hline 5 & 5 & 0 & 0 \\
\hline 10 & 5 & 0 & 0 \\
\hline 15 & 5 & 0 & 0 \\
\hline 20 & 5 & 0 & 0 \\
\hline
\end{tabular}

Control received $0.3 \mathrm{ml}$ Acacia $(2 \% \mathrm{w} / \mathrm{v})$ solution
The postprandial test results of the different extracts, $T$. africana root bark extract and $T$. globiferus extract respectively and the mixture (1:1) are shown in Fig. 1. The extract mixture had the most significant postprandial hypoglycemic activity compared to treatment with the separate extracts. The administration of different doses of the extracts separately and with the mixture did not produce noticeable signs of changes in the behaviour of the animals during the seven days of the observed period. Although there was noticeable increase in appetite and water consumption in the diabetic and normal animals treated with the various extracts, there was however no significant $(p>0.05)$ weight gain by the animals (Table 2).

GP4 normal rats treated with extracts mixture (1:1) $250 \mathrm{mg} / \mathrm{kg}$ bwt. GP 5 diabetic rats treated with Glibenclamide (reference drug) 600ug/kg bwt. GP 6 diabetic rats treated with $0.5 \mathrm{ml}$ of Acacia $(2 \% \mathrm{w} / \mathrm{v})$ solution

The effects of the extracts/glibenclamide on the biochemical parameters after treatment are summarized in Table 3 . There was significant $(p>$ 0.05 ) reduction in the plasma glucose levels in the animals treated with the separate extracts and the mixture (1:1). The reduction was comparable to the value obtained from treatment with the reference drug, glibenclamide. There were also significant reductions in the plasma levels of triglycerides (TG), total cholesterols (TC), and low density lipoproteincholesterol (LDL- cholesterol) in the extract treated compared to negative control and a significant increase in the high density lipoprotein-cholesterol (HDL- cholesterol).

There was significant $(p \geq 0.05)$ increase in AST and ALT in all the extracts treated compared to the normal control. There was marginal increase in total plasma protein in all the extract treated groups while significant increase in the albumin, creatinine and urea concentrations occurred compared to normal control. However, total protein and bilirubin levels of the treated groups did not vary markedly from the normal

Table 5 showed the results of weight variation of the vital organs. There were insignificant changes in the weight of vital organs of the treated animals compared to normal control.

Haematological parameters result is shown in Table 4.There was marginal decrease in $\mathrm{RBC}, \mathrm{Hb}$, while significant increase in PCV level occurred compared to normal. On the other hand, WBC content showed marginal increase. 
The histology of pancreatic tissue of normal rats, diabetic rats but treated with the extracts separately, the mixture, glibenclamide and diabetic untreated are shown in Figure 2. The photomicrograph of normal pancreatic tissue (Fig. 2a) demonstrated compact islet organization with beta cells highlighted in situ. The photomicrograph of pancreatic tissue of diabetic animals treated with $T$. globiferus (Fig. 2b) showed extensive necrotic changes but with equally considerable number of beta cells survivor. In fig. $2 \mathrm{c}$, the photomicrograph of $T$. africana treated showed few areas of necrotic changes with significant presence of survivor beta cells. The photomicrograph of extract mixture treated (Fig. 2 d) showed few areas of necrotic changes with more numerous beta cells. The pancreatic tissue of treatment with glibenclamide (Fig. 2e) showed marked necrotic changes with scanty survivor beta cells. The pancreatic tissue of diabetic untreated rats (Fig. 2f) showed more severe lesion in pancreatic islet cells indicating amorphous oesinophilia with vacuoles interspacing.

The preliminary phytochemical screening (Fig. 6) of both plants indicated the presence of flavonoids, proteins and steroidal compounds. T. globiferus contained saponins while $T$. africana was found to contain polyphenol and tannins.

Table 2. Weight variation of the diabetic animal treated with (1:1) mixture, individual components respectively, glibenclamide and the control

\begin{tabular}{|l|l|l|l|l|}
\hline & Day 0 & Day 7 & Day 14 & Day 21 \\
\hline GP1 & $120.0 \pm 1.1$ & $124.0 \pm 1.1$ & $128.0 \pm 1.1$ & $122.5 \pm 1.0$ \\
\hline GP2 & $120.0 \pm 1.1$ & $115.0 \pm 1.0$ & $126.0 \pm 1.3$ & $124.0 \pm 1.1$ \\
\hline GP3 & $150.0 \pm 0.7$ & $155.0 \pm 1.09$ & $153.0 \pm 1.1$ & $156.0 \pm 1.2$ \\
\hline GP4 & $150.0 \pm 0.8$ & $167.0 \pm 1.2$ & $170.0 \pm 1.0$ & $175.0 \pm 1.5$ \\
\hline GP5 & $150.1 \pm 0.7$ & $160.0 \pm 0.8$ & $163.1 \pm 1.5$ & $165.8 \pm 1.6$ \\
\hline GP6 & $140.1 \pm 3.5$ & $143.9+2.3$ & $147.1 \pm 2.7$ & $150.7 \pm 0.2$ \\
\hline
\end{tabular}

GP 1. Diabetic rats treated with the extracts mixture $(1: 1) 250 \mathrm{mg} / \mathrm{kg}$ bwt; GP 2 diabetic rats treated with Treculia africana root extract $250 \mathrm{mg} / \mathrm{kg}$ bwt; GP 3 diabetic rats treated with Tapinanthus globiferus extract $250 \mathrm{mg} / \mathrm{kg}$ bwt

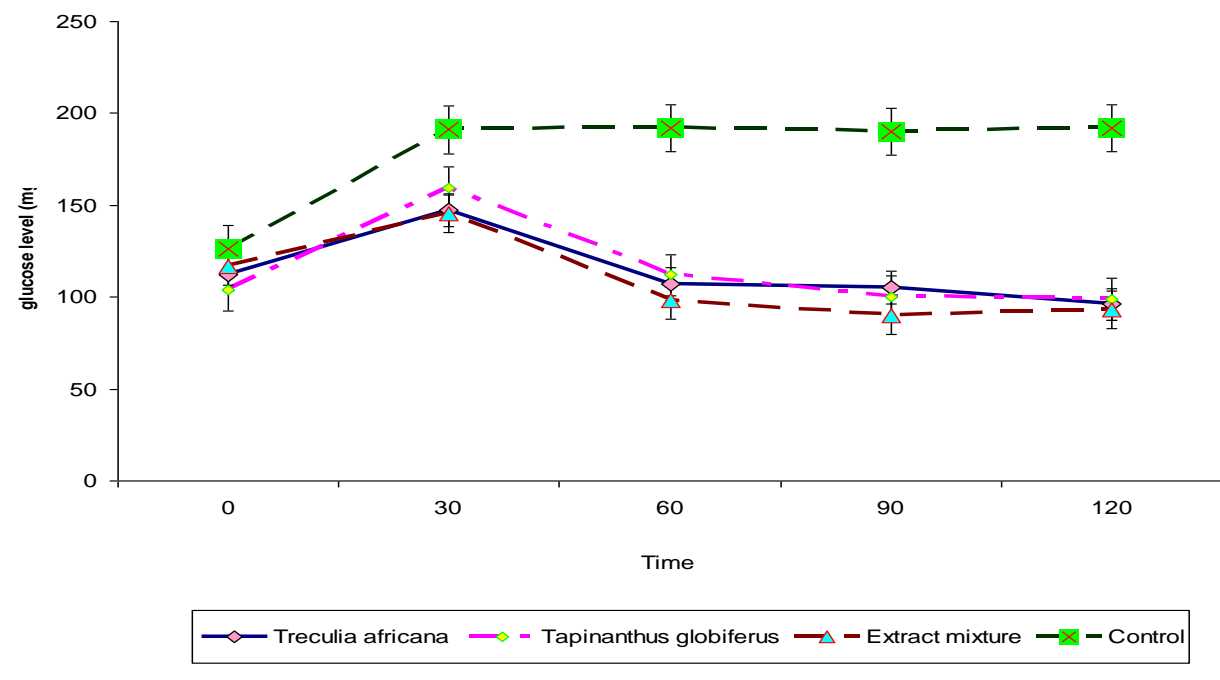

Figure 1: Postprandial plasma glucose levels of the extracts separately, the mixture and the control. 
Agric. Biol. J. N. Am., 2012, 3(6): 237-246

Table 3: Plasma glucose level and other biochemical profiles of diabetic rats but treated with the extracts mixture (1:1), the extracts separately, normal untreated, glibenclamide and diabetic but treated with Acacia solution (control).

\begin{tabular}{|l|l|l|l|l|l|l|}
\hline & GP1 & GP2 & GP3 & GP4 & GP5 & GP6 \\
\hline Glu $(\mathrm{mmol} / \mathrm{L})$ & $1.8 \pm 0.9^{*}$ & $2.0 \pm 1.1^{*}$ & $2.4 \pm 1.4^{*}$ & $1.7 \pm 0.8^{*}$ & $1.9 \pm 3.1^{*}$ & $18.9 \pm 0.2$ \\
\hline $\mathrm{TG}(\mathrm{mmol} / \mathrm{L})$ & $0.8 \pm 0.8^{*}$ & $0.8 \pm 1.0^{*}$ & $1.0 \pm 0.4^{* *}$ & $0.7 \pm 0.1^{*}$ & $0.7 \pm 0.8^{*}$ & $1.5 \pm 1.3$ \\
\hline $\mathrm{T} . \mathrm{C}(\mathrm{mmol} / \mathrm{L})$ & $1.0 \pm 0.2^{* *}$ & $0.9 \pm 0.6^{*}$ & $1.1 \pm 0.0^{* *}$ & $0.9 \pm 0.1^{*}$ & $1.4 \pm 0.2$ & $1.9 \pm 0.1$ \\
\hline $\mathrm{HDL}(\mathrm{mmol} / \mathrm{L})$ & $1.3 \pm 0.5^{*}$ & $1.3 \pm 0.1^{*}$ & $1.0 \pm 0.0^{* *}$ & $1.1 \pm 0.0^{* *}$ & $1.6 \pm 0.2^{*}$ & $0.6 \pm 0.1$ \\
\hline $\mathrm{LDL}(\mathrm{mmol} / \mathrm{L})$ & $0.2 \pm 0.0^{*}$ & $0.2 \pm 0.5^{*}$ & $0.2 \pm 0.1^{* *}$ & $0.5 \pm 0.1^{*}$ & $0.4 \pm 0.1^{* *}$ & $0.9 \pm 0.2$ \\
\hline T.Protein(g/L) & $59.3 \pm 3.6^{*}$ & $51.5 \pm 3.8^{*}$ & $57.9 \pm 2.9^{*}$ & $51.4 \pm 3.1^{*}$ & $47.3 \pm 2.1^{*}$ & $22.2 \pm 2.0$ \\
\hline ALB $(\mathrm{g} / \mathrm{L})$ & $45.1 \pm 1.1^{*}$ & $37.8 \pm 1.5^{*}$ & $46.4 \pm 1.2^{*}$ & $59.7 \pm 1.7^{*}$ & $50.3 \pm 1.2^{*}$ & $28.3 \pm 2.7$ \\
\hline AST $(\mathrm{I} . \mathrm{U} / \mathrm{L})$ & $77.6 \pm 9.4^{*}$ & $80.1 \pm 6.2^{*}$ & $79.9 \pm 4.6^{*}$ & $57.0 \pm 0.3^{*}$ & $54.6 \pm 2.7$ & $31.0 \pm 2.4$ \\
\hline ALT I.U/L) & $20.2 \pm 7.4^{*}$ & $24.2 \pm 3.5^{*}$ & $19.2 \pm 3.4^{* *}$ & $12.4 \pm 3.4$ & $11.5 \pm 0.5$ & $11.9 \pm 1.5$ \\
\hline Creat $(\mathrm{mg} / \mathrm{dl})$ & $28.3 \pm 0.6^{*}$ & $41.4 \pm 0.3^{*}$ & $32.6 \pm 0.9^{*}$ & $17.8 \pm 1.2^{*}$ & $36.5 \pm 2.6^{*}$ & $79.5 \pm 3.5$ \\
\hline T.Bil $(\mu \mathrm{mol} / \mathrm{L}))$ & $0.3 \pm 0.0^{*}$ & $0.3 \pm 0.0^{*}$ & $0.3 \pm 0.0^{*}$ & $0.1 \pm 0.0^{*}$ & $0.5 \pm 5.2^{*}$ & $100.6 \pm 4.6$ \\
\hline ALP $(\mu \mathrm{mol} / \mathrm{L}))$ & $168.7 \pm 5.1^{*}$ & $143.3 \pm 6.8^{*}$ & $176.0 \pm 2.9^{*}$ & $116.7 \pm 6.5^{*}$ & $207.0 \pm 5.2^{*}$ & $280.1 \pm 2.6$ \\
\hline Urea $(\mu \mathrm{mol} / \mathrm{L})$ & $8.9 \pm 0.8^{*}$ & $9.9 \pm 1.2^{*}$ & $9.8 \pm 0.9^{*}$ & $4.2 \pm 0.3^{*}$ & $8.6 \pm 1.1^{*}$ & $16.9 \pm 3.6$ \\
\hline
\end{tabular}

$\mathrm{N}=5$, Value $=$ mean \pm sem ${ }^{*} p \leq 0.05 .{ }^{* *} p \leq 0.01$ (The difference is significant).

GP 1, Diabetic rats treated with the extracts mixture (1:1) $250 \mathrm{mg} / \mathrm{kg}$ bwt; GP 2, diabetic rats treated with Treculia africana root extract $250 \mathrm{mg} / \mathrm{kg}$ bwt; GP 3, diabetic rats treated with Tapinanthus globiferus extract 250mg/kg bwt;

GP4, normal rats; GP 5, diabetic rats treated with Glibenclamide (reference drug) $600 \mathrm{ug} / \mathrm{kg}$ bwt; GP 6 , diabetic rats treated with $0.5 \mathrm{ml}$ of Acacia $(2 \% \mathrm{w} / \mathrm{v})$ solution (control).

Table 4: Haematological and blood chemistry parameters of diabetic rats treated with the extracts mixture (1:1), the extracts separately, normal untreated, glibenclamide and diabetic but treated with Acacia solution (control).

\begin{tabular}{|l|l|l|l|l|l|l|}
\hline & GP1 & GP2 & GP3 & GP4 & GP5 & GP6 \\
\hline $\mathrm{RBC}\left(\times 10^{6}\right)$ & $5.5 \pm 0.6$ & $4.6 \pm 0.1$ & $5.4 \pm 0.0$ & $6.4 \pm 0.0$ & $5.5 \pm 0.1$ & $4.0 \pm 0.1$ \\
\hline $\mathrm{Hb}(\mathrm{g} / \mathrm{dl})$ & $11.9 \pm 2.3$ & $11.7 \pm 0.4$ & $10.4 \pm 0.9$ & $14.2 \pm 1.2$ & $12.6 \pm 0.9$ & $7.3 \pm 0.4$ \\
\hline $\mathrm{WBC}\left(\times 10^{3}\right)$ & $8.3 \pm 0.1$ & $8.7 \pm 0.1$ & $6.5 \pm 0.1$ & $5.4 \pm 0.1$ & $5.3 \pm 0.1$ & $5.8 \pm 0.1$ \\
\hline $\mathrm{MCV}(\mathrm{FL})$ & $65.2 \pm 2.1$ & $56.2 \pm 2.3$ & $51.9 \pm 2.0$ & $63.3 \pm 2.6$ & $54.2 \pm 2.3$ & $57.4 \pm 2.0$ \\
\hline $\mathrm{MCH}(\mathrm{pg})$ & $19.6 \pm 0.0$ & $19.1 \pm 0.2$ & $19.3 \pm 0.3$ & $20.6 \pm 0.4$ & $18.9 \pm 0.3$ & $18.8 \pm 0.5$ \\
\hline $\mathrm{MCHC}(\mathrm{g} / \mathrm{dl})$ & $30.1 \pm 0.6$ & $34.0 \pm 0.6$ & $37.2 \pm 0.7$ & $32.5 \pm 0.6$ & $39.9 \pm 0.9$ & $32.8 \pm 0.7$ \\
\hline $\mathrm{PCV}(\%)$ & $31.7 \pm 1.4^{*}$ & $33.7 \pm 1.7^{*}$ & $27.9 \pm 1.4^{*}$ & $44.4 \pm 2.1^{*}$ & $35.5 \pm 2.5^{*}$ & $17.1 \pm 1.0$ \\
\hline
\end{tabular}

$\mathrm{N}=5$, Value $=$ mean \pm sem ${ }^{*} p \leq 0.05 .{ }^{* *} p \leq 0.01$ (The difference is significant)

GP 1, Diabetic rats treated with the extracts mixture (1:1) $250 \mathrm{mg} / \mathrm{kg}$ bwt; GP 2, diabetic rats treated with Treculia africana root extract $250 \mathrm{mg} / \mathrm{kg}$ bwt; GP 3, diabetic rats treated with Tapinanthus globiferus extract 250mg/kg bwt; GP 4, normal untreated rats; GP 5, diabetic rats treated with Glibenclamide (reference drug) $600 \mathrm{ug} / \mathrm{kg}$ bwt; GP 6 , diabetic rats treated with $0.5 \mathrm{ml}$ of Acacia (2\%w/v) solution.

Table 5: Organs weights variation of diabetic rats treated with the extracts mixture (1:1), the extracts separately, normal untreated, glibenclamide and diabetic but treated with Acacia solution (control).

\begin{tabular}{|l|l|l|l|l|l|l|}
\hline Organ weight/ 100g & GP1 & GP2 & GP3 & GP4 & GP5 & GP6 \\
\hline Heart & $0.4 \pm 0.0$ & $0.3 \pm 0.1$ & $0.3 \pm 0.1$ & $0.4 \pm 0.1$ & $0.7 \pm 0.1$ & $0.6 \pm 0.1$ \\
\hline Kidney & $0.9 \pm 0.1$ & $0.8 \pm 0.2$ & $0.7 \pm 0.5$ & $0.8 \pm 0.8$ & $0.9 \pm 0.0$ & $1.0 \pm 0.5$ \\
\hline Liver & $4.8 \pm 0.4$ & $4.0 \pm 0.2$ & $4.4 \pm 0.6$ & $3.9 \pm 0.7$ & $4.1 \pm 0.8$ & $4.9 \pm 0.6$ \\
\hline
\end{tabular}

$\mathrm{N}=5$, Value $=$ mean \pm sem ${ }^{*} \mathrm{p} \leq 0.05 .{ }^{* *} \mathrm{p} \leq 0.01$ (The difference is significant)

GP 1, Diabetic rats treated with the extracts mixture (1:1) $250 \mathrm{mg} / \mathrm{kg}$ bwt; GP 2, diabetic rats treated with Treculia africana root extract $250 \mathrm{mg} / \mathrm{kg}$ bwt; GP 3, diabetic rats treated with Tapinanthus globiferus extract $250 \mathrm{mg} / \mathrm{kg}$ bwt; GP 4, normal untreated rats; GP 5, diabetic rats treated with Glibenclamide (reference drug) $600 \mathrm{ug} / \mathrm{kg}$ bwt; GP 6 , diabetic rats treated with $0.5 \mathrm{ml}$ of Acacia $(2 \% \mathrm{w} / \mathrm{v})$ solution.

Flavonoids 
Agric. Biol. J. N. Am., 2012, 3(6): 237-246

Fig. 2: The pancreatic tissue of diabetic rats treated with the extracts separately, the extracts mixture (1:1), glibenclamide and untreated diabetic rats respectively

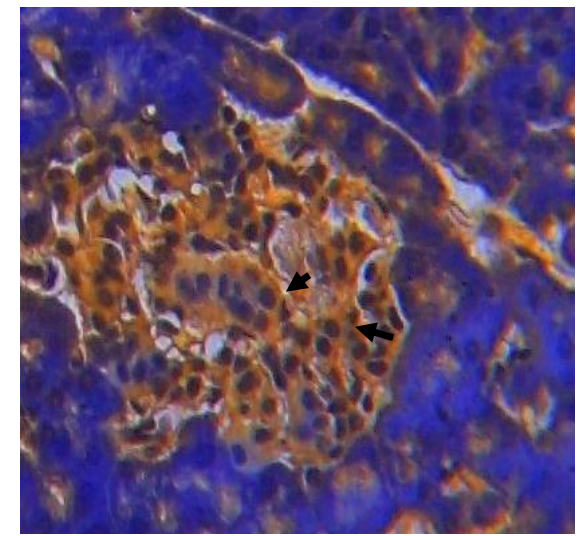

$2 a$

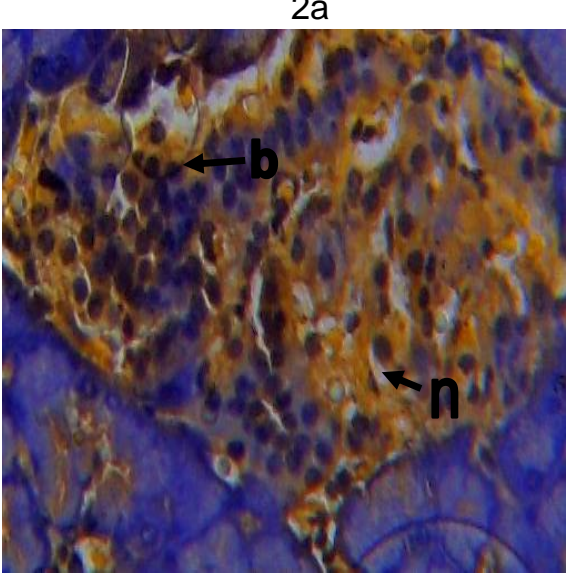

2c

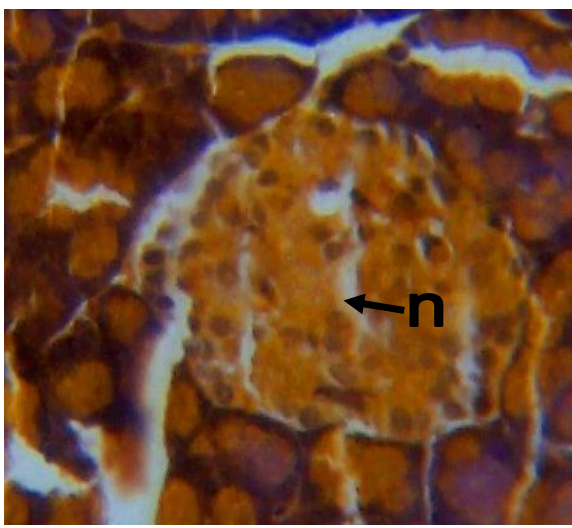

$2 e$

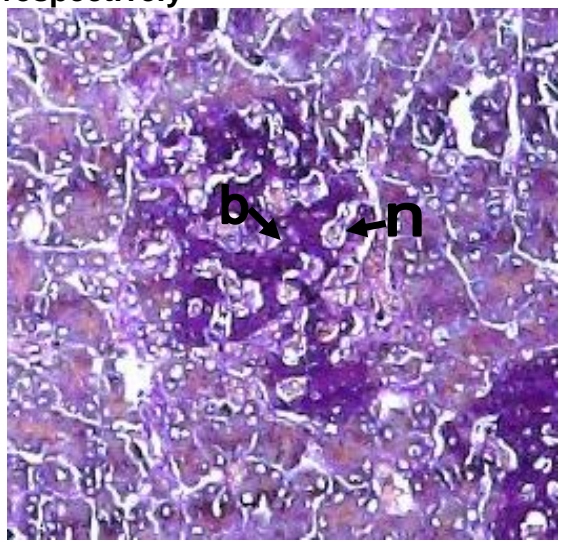

$2 b$

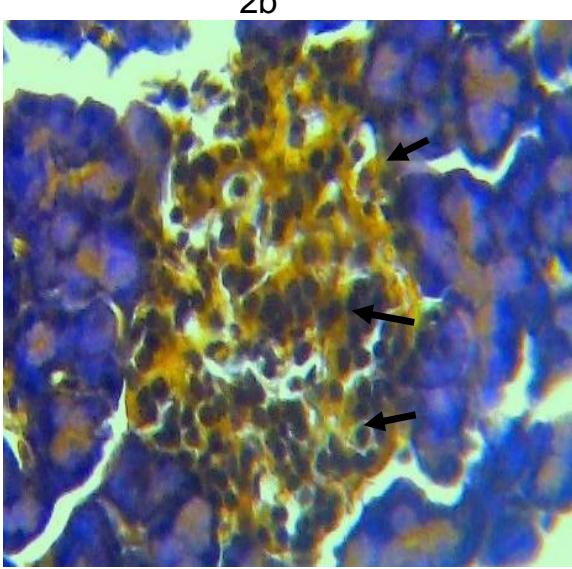

$2 d$

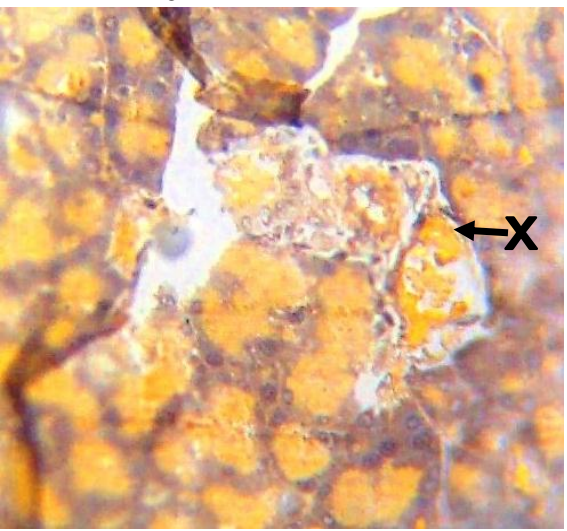

$2 f$

Fig. 2a showed normal morphology of pancreatic islet with dense presence of darkly stained beta cells (arrowed). X 400

Fig. $2 \mathrm{~b}$ (T. globiferus treated) showed area of necrosis ( $\mathrm{n}$ ) with spots of survivor beta cells (b) widely dispersed. $\times 400$

Fig. 2c ( $T$. africana treated) showed area of necrotic changes (n) and darkly stained beta cells (b). X 400

Fig.2d (Extract mixture treated) showed mild necrotic changes with cluster of beta cells survivor (arrowed). $X$ 400

Fig.2e (Glibenclamide treated) indicated area of necrotic changes (n) with scanty beta cells. X 400

Fig.2f (Diabetic untreated) showed severe beta cell necrosis and vacuoles (X). X 400 
Table 6: The preliminary phytochemical screening of the extracts

\begin{tabular}{|l|c|c|}
\hline Test & T. africana & T.globeferus \\
\hline Alkaloids & - & - \\
\hline Carbohydrates & + & + \\
\hline Reducing Sugars & + & - \\
\hline Tannins (Phlobotanins) & + & - \\
\hline Saponins & - & + \\
\hline Steroidal compound & + & + \\
\hline Phenol & ++ & - \\
\hline
\end{tabular}

\section{DISCUSSION}

Herbal medicines have received greater attention as alternative to clinical therapy in recent times leading to subsequent increase in their demand (Sushruta et al., 2006; Ogbonnia et al., 2010). In rural communities, the exclusive use of herbal drugs, prepared and dispensed by herbalists without formal training, for the treatment of diseases is still very common. Experimental screening method is, therefore, required for the evaluation of the claimed activity, and to ascertain the safety and efficacy of these herbal products as well as to establish their active constituents (Ogbonnia et al., 2008).

It could be interpreted from the result that the median acute toxicity $\left(\mathrm{LD}_{50}\right)$ value of the mixture was higher than $20 \mathrm{~g} / \mathrm{kg}$ bwt. According to Ghosh (1984) and Klaasen et al., (1995), the mixture can be classified as being non-toxic, since the $\mathrm{LD}_{50}$ by oral route was found to be much higher than WHO toxicity index of 2 $\mathrm{g} / \mathrm{kg}$.

The extracts recipe of $T$. globiferus, $T$. africana and the combined (1:1) at $250 \mathrm{mg} / \mathrm{kg}$ bwt proved to have a similar postprandial plasma sugar lowering effect which demonstrated that the constituents might have some additive potentials. The good postprandial effect of the extracts could be attributed to aglucosidase inhibitory activities associated with this class of drugs.

The non significant weight gain observed in the diabetic animals treated with the drug clearly suggested that the extracts might not have had the obesity forming tendency, which is one of the undesirable side effects normally encountered when treating diabetes with sulphonylureas. There were also no changes observed in the macroscopic examinations of the organs of the diabetic animals treated with the extracts or glibenclamide

Experimental diabetes in many animal species is achieved by intraperitoneal injection of alloxan monohydrate, a beta cytotoxin, which causes free radicals release. These free radicals undergo dismutation to hydrogen peroxide resulting to rapid destruction of the $\beta$ cells of the pancreas which predisposes to diabetes and diabetic complications. The amelioration of deranged blood glucose and lipid profile with the extracts used separately for the treatment and their mixture demonstrated that they possess anti-hyperglycaemic and antihyperlipidaemic activities. This in effect justified their use in alternative therapy for the management of diabetes and diabetes related cases. It was apparent however that the above activity was more pronounced in the extract mixture suggesting synergy of action between the extracts active components. In most traditional medical treatment of diabetes, compound recipes are more often used than single recipes due to consideration of integrated effects of compound recipes (Li et al., 2004). It was also apparent from pancreatic tissue morphology that the animals treated with the extract mixture showed most significant beta cells recovery which implied that the mixture more effectively ameliorated the diabetogenic agent activity.

The liver and heart release AST and ALT, and an elevation in their plasma levels are usually reliable indices to inflammatory changes in both organs (Mythilypriya et al., 2007; Wasan et al., 2001). ALT and AST levels were significantly increased in the groups that received the various extracts particularly the group treated with the $T$. africana extract. In view of the foregoing, the tendency that the extracts might be injurious to the hepatic tissue was likable. It could also imply that the extracts might have inflicted harmful effect on the cardiac tissue following the report that elevated blood level of AST is known to exhibit such tendency (Crook, 2006).

There was increase in creatinine and urea levels in the extracts treated groups compared to the normal value which suggested that renal dysfunction associated with diabetic condition may have been initiated by the diabetic agent (Tietz, 1982).

Most plasma proteins are synthesized and degraded in the liver therefore a measurable increase in the blood circulation might reflect either an impaired hepatocellular production and/or increased catabolism that may have occurred in various physiological or pathological processes (Johnson, 1999). The fall in albumin level in this study may be due to nephritis. 
Although the RBC and $\mathrm{Hb}$ content of diabetic animals treated with the extracts were less than the normal values, there was however marked increase compared to the diabetic control. The increase in levels following extract treatment may be due to changes in the rate of the RBCs production. Therefore the extract may have the potential to stimulate erythropoietin release in the kidney as have been reported with some plants (Mbaka et al., 2010).

The calculated RBC indices, $\mathrm{MCH}, \mathrm{MCV}$ and $\mathrm{MCHC}$ used in anaemia diagnosis were not significantly altered in the extract treated animals which suggested that the activity of the extracts had minimal effect on the size of RBC.

Plant secondary metabolites like flavonoids and polyphenols are known for their antioxidant activities as well as shown to possess hypoglycaemic activity (Mowla et al., 2009).

\section{CONCLUSION:}

T.africana and T.globiferus separately and the mixture (1:1) were observed to have good postprandial sugar lowering effect with the mixture exhibiting more activity. The extracts equally produced significant anti-hyperglycaemic and antihyperlipidaemic effect. They were observed not to be toxic in short term use but showed tendency to predispose to cardiac, hepatic and nephro-toxicity in long term use. Therefore it is strongly advised to limit their use to a short term to minimize the risk of exposure to other health challenges.

\section{REFERENCES}

Barnett, A. H and O'Gara, G (2003). Diabetes and the heart: In clinical practice series. Churchhill Livingstone, Edinburgh, UK.

Burger, C., Fischer, D.R., Cordenuzzi, D.A., Batschauer de Barba, A.P., Filho, V.C and Soares des Santos, A.R (2005). Acute and Subacute toxicity of the hydroalcoholic extract from Wedelia paludosa (Acmela brasiliensis) (Asteraceae) in Mice. J. Pharm. Sc. 8 (2): 370-373.

Crook, M. A (2006). Clinical chemistry and metabolic medicine. 7th Edition. Hodder Arnold, London, pp 426.

Dacie, J. C and Lewis, S. M (1984). Practical haematology $5^{\text {th }}$ Edn, Churchill Livingstone, London.

Egwim, E (2005). Hypoglycaemic potencies of crude ethanolic extracts of Cashew roots and unripe Pawpaw fruits in guinea pigs and rats. J. Herb. Pharmacotherapy. 5 (1): 27-34.
Ekaidem, I. S., Akpanabiatu, M. I., Uboh, F. E and Eka, O. $U$ (2006). Vitamin B12 supplementation: effects on some biochemical and haematological indices of rats on phenytoin administration. Biochem. 18 (1): 31- 37.

El-Nagar, B. E. M., Bartó.Íková, L., Îemlâka, M., Vajdlenka, E., Rabi.ková, M., Stranadová, V and Neâas, J (2005). Antidiabetic effect of Cleome droserifolia aerial parts:lipid peroxidation-induced oxidative stress in diabetic rats. Acta Vet. Brno. 74: 347-352.

Farnsworth, R. N (1966). A Review: Biological and Phytochemical Screening of Plants. J. Pharm. Sc. 55 (3): 225- 275.

Gale, A.M (2001). The discovery of type I diabetes. Diabetes. 50: 217-226.

Ghosh, M. N (1984). Fundamentals of experimental pharmacology, (2 ${ }^{\text {nd }}$ Eds.), Scientific Book Agency, Calcutta, pp 154-157.

Grundy, M.S., Benjamin. J.I., Burke, L.G., Chait. A., Eckel, H.R., Howard, V.B., Mitch, M., Smith, C.S and Sowers, R.. J (1999). Diabetes and cardiovascular disease: A statement for health care professionals from The America Heart Association. Circulation. 100:11341146.

Hussain, A and Eshrat, H. M (2002). Hypoglycemic, hypolipidemic and antioxidant properties of combination of Curcumin from Curcuma longa Linn and partially purified product from Abroma augusta, Linn. in streptozotocin induced diabetes. Ind. J Clin. Biochem. 17 (2): 33- 43.

Houghton, P. J and Raman, A (1998). Laboratory handbook for the Fractionation of Natural Extracts. Chapman and Hall, London. $3^{\text {rd }}$ ed. ISBN 041274910 6.

Klaasen, C. D., Amdur, M.O and Doull, J (1995). Casarett and Doull's Toxicology: The basic science of poison. 8th Edition. Mc Graw Hill, USA, pp 13-33.

Li, W. L., Zheng, H. C., Bukuru, J and De-Kimpe, N (2004). Natural medicines used in the traditional Chinese medical system for therapy of diabetes mellitus. J. Ethnopharmacol. 92: 1-21.

International Diabetes Federation (2009). Diabetes Atlas. $4^{\text {th }} \mathrm{ed}$. Available at http://www.diabetesatlas.org/map. viewed on $10 / 7 / 2010$.

Johnson, A.M (1999). Low levels of plasma proteins: Malnutrition or inflammation? Clin. Chem. Lab. Med. 37: 91-96.

Mbaka, G. O., Adeyemi, O. O., Noronha, C. C., Anunobi, C. C and Okanlawon, A. O (2009). Anti- hyperglycaemic and hypoglycaemic effects of ethanol root extract of Sphenocentrum jollyanum in normal and alloxaninduced diabetic rabbits. Braz. J. Morphol. Sci. 26 (2): 123-127. 
Mbaka, G. O., Adeyemi, O. O and Oremosu, A. A (2010). Acute and sub-chronic toxicity studies of the ethanol extract of the leaves of sphenocentrum jollyanum (menispermaceae). Agric. Biol. J. N. Am. 1 (3): 265272.

Mowla, A., Alauddin, M., Rahman, A and Ahmed, R (2009). Antihyperglycemic effect of Trigonella foenumgraecum(fenugreek) seed extract in alloxan-induced diabetic rats and its use in diabetes mellitus:A brief qualitative phytochemical and acute toxicity test on the extract. Afri. J. Trad. Comp. Alter. Med 6 (3): 255-261.

Mythilypriya, R., Shanthi, P and Sachdanandam, P (2007). Oral acute and sub-acute toxicity studies with Kalpaamruthaa ,a modified indigenous preparation, on rats. J. Health Sc. 53 (4): 351-358.

Noor, A., Gunasekaran, S., Manickam, A.S and Vijayalakshmi, M.A (2008). Antidiabetic activity of Aloe vera and Histology of organs in Streptozotocin induced diabetes rats. Current Sc. 94 (8): 1070-1075.

Odebiyi, O. O and Sowora, E. A (1978). Phytochemical screening of Nigerian medicinal plants. LLoyda. 41: 234-236.

Odugbemi, T (2006). Outline and Pictures of Medicinal Plants from Nigeria. University of Lagos Press Lagos, Nigeria. $1^{\text {st }}$ Ed. ISBN978-38235-9-0, pp. 144 \&148.

Ogbonnia, S.O., Enwuru, N.V., Onyemenem, E.U., Oyedele, G.A and Enwuru, C.A (2008). Phytochemical Evaluation and Antibacterial profile of Treculia africana Decne Bark Extract on Gastro-intestinal pathogens. Afri. J. Biotech. 7 (10): 1385-1389.

Ogbonnia, S.O., Odimegwu, J. I and Enwuru, V. N (2008). Evaluation of hypoglycemic effect of aqueous Ethanol Extract of Treculia africana Decne and Bryophyllum Pinnatum Lam. and their mixture on streptozotocin (STZ) - induced diabetic rats. Afri. J. Biotech. 7 (15): 2535-2539.

Ogbonnia, S.O., Mbaka, G.O., Adekunle, A., Anyika, E.O., Gbolade, O.E and Nwakakwa N (2010). Effect of polyherbal formulation, Okudiabet on Alloxan - Induced diabetic rats. Agric. Bio. J. N. Am. 1 (2): 139-145.

Park, J., Bong, H., Jeong, H., Kim, K.Y., Kim, J.Y and Kwon, O (2009). Post-prandial hypoglycemic effect of mulberry leaves in Goto-kakizaki rats and counterpart control Wistar rats. Nutri. Res. Pract. 3(4): 272-278.
Pari, L and Saravanan, R (2004). Antidiabetic effect of Diasulin, an herbal drug, on blood glucose, plasma insulin and hepatic enzymes of glucose metabolism in hyperglycaemic rats. Diab. Obes. Metab. 6 (4): 286291.

Richert, K., Martinez., R. R and Martinez, T. T (1999). Pharmacist knowledge of common herbal preparations. Proc. West. Pharmacol. Soc. 42: 1-2.

Shah, A. M. A., Garg, S.K and Garg, K.M (1997). Subacute toxicity studies on pendimethalin in rats. Ind. J. Pharmacol. 29: 322-324.

Senthilyel, G., Jegadeesan, M., Austin, A., Thirugnanasambanthan, P., Mayisurem, E., Balasubramanian, M. Narayanan, $\mathrm{N}$ and Viswanathan, $S$ (2006). Effect of a poly-herbal formulation (Diarun plus) on Streptozotocin induced experimental diabetes. Int. J. Trop. Med. 2:88-92.

Sofowora, A (1993). Screening plants for bioactive agents. In medicinal plants and traditional in Africa. Spectrum Books Ltd Ibadan, 2ed, pp 134-156.

Sushruta, K., Satyanarayana, S., Srinivas, N and Sekhar, R. J (2006). Evaluation of the blood-glucose reducing effects of aqueous extracts of the selected Umbellifereous fruits used in culinary practice. Trop. J. Pharma. Res. 5 (2): 613-617.

Tietz, N.W (1982). Blood gases and electrolytes. In: N.W. Tietz, (Ed.) Fundamentals of clinical chemistry. $2^{\text {nd }}$ Edition, W.B. Saunders Company, Philadelphia, USA, pp 849-944.

Walter, B. J (1977). An Introduction to the principles of disease. W.B. Saunders Company. Philadelphia USA, pp 374-377.

Wasan, K. M., Najafi, S., Wong, J and Kwong, M (2001). Assessing plasma lipid levels, body weight, and hepatic and renal toxicity following chronic oral administration of a water soluble phytostanol compound FM-VP4, to gerbils. J. Pharm. Sci. 4 (3): 228-234.

Yinegar, H., Yewhalaw, D and Teketay, D (2008). Ethnomedical plant knowledge and practice of the Oromo ethnic group in South Western Ethiopia. J. Ethnobiol. Ethnomed. 4 (11): 1-10. Available at http://www.ethnobiomed.com/content/4/1/11 viewed 10/7/2010. 